19: PERSPECTIVES IN CRITICISM 


\section{PERSPECTIVES IN CRITICISM}

1: Elements of Critical Theory

2: The Disinherited of Art

3: Stream of Consciousness in the Modern Novel

4: The Poet in the Poem

5: Arthurian Triptych

6: The Brazilian Othello of Machado de Assis

7: The World of Jean Anouilh

8: A New Approach to Joyce

9: The Idea of Coleridge's Criticism

10: Introduction to the Psychoanalysis of Mallarmé

11: This Dark Estate: A Rearing of Pope

12: The Confucian Odes of Ezra Pound

13: The Religious Sonnets of Dylan Thomas

14: Interpretations in Shakespeare's Sonnets

15: Tennyson's Maud: The Biographical Gentsis

16: Joyce's Benefictions

17: James Thomson (B.V.): Beyond "The City"

18: Syntax in English Poetry, 1870-1930

19: The Gaiety of Language 


\section{9:}

Frank Lentricchia

The Gaiety of Language:

An Essay on the Radical

Poetics of W. B. Yeats and

Wallace Stevens

UNIVERSITY OF CALIFORNIA PRESS

Berkeley and Los Angeles

1968 
(C) 1968 by The Regents of the University of California

University of California Press Berkeley and Los Angeles, California Cambridge University Press

London, England 
To my mother and father, i migliori parenti 
Natives of poverty, children of malheur, The gaiety of language is our seigneur.

WALLACE STEVENS, "Esthetique du Mal"

Follow, poet, follow right

To the bottom of the night,

With your unconstraining voice

Still persuade us to rejoice;

With the farming of a verse

Make a vineyard of the curse,

Sing of human unsuccess

In a rapture of distress;

In the deserts of the heart

Let the healing fountain start,

In the prison of his days

Teach the free man how to praise.

W. H. AUDEN,

"In Memory of W.B. Yeats" 